\title{
Passing the Torch: \\ Reminiscences with Frances Bryant Bradburn, Editor Emerita, North Carolina Libraries, 1985-2002
}

\author{
by Plummer Alston "Al" Jones, Jr.
}

PAJ: Frances, we have been colleagues and friends since 1989 when I began my tenure with the Editorial Board of North Carolina Libraries. You have been an inspiration to me and to all your many friends in North Carolina and across the country. Your tireless dedication to making North Carolina Libraries the best state library association journal in the country has resulted in the journal winning the coveted H. W. Wilson Award for Best State Library Journal, not once, but twice, in 1992 and 1995.

We as members of the North Carolina Library Association owe you a debt of gratitude that we will never be able to repay fully. I hope that you will allow us one further favor-sharing with us your reminiscences of your seventeen-year tenure as Editor of North Carolina Libraries.

When you began your tenure as Editor of North Carolina Libraries in 1985, at what point were you in your professional career? What convinced you to take on the challenge? What were the concerns facing not only North Carolina Libraries but also the North Carolina Library Association?

FBB: Goodness, I was so new! I had just been hired as a regional media and technology consultant by the Department of Public Instruction, and was excited and enthusiastic about everything. Frankly, I didn't need any convincing once my boss, Sam Shugart, said OK. That was the big hurdle - "getting permission." I truly wanted and needed to work on this journal. As my mother has said, "Frances has always edited something." It's a great love. As for concerns facing both the journal and the Association, we were really in one of those golden eras - at least I remember it as that - in which there were very few problems. There seemed to be enough money, everyone was getting along (at least I thought they were!), and professional associations were considered vital to a person's professional career. It was a slower, quieter time - and I can't believe I'm actually saying that. I sound like my grandmother!

PAJ: What kept you going through seventeen years of editorship? Were their mentors along the way who offered expertise and/or encouragement?

FBB: Definitely the people, especially the NCL Editorial Board members. People so enjoyed doing a good job. We have just always had the best time together; it was a social as well as a professional environment for all who participated. Another important thing that kept me going was that the membership continuously gave me feedback that the journal was important to them. So many people told us what was important and we worked really hard to create a journal that met the 
entire membership's needs, not just one segment of the Association. As for mentors, frankly the gentleman who handled the printing of the journal when I took over, Bob Renkenbil, basically walked me through the process regardless of what it was. He taught me how to do a paste-up — that's how NCL was laid out then - it was like cutting out paper dolls - how to calculate pagination, everything. He was a true friend and it was very difficult to tell him that we were moving on to the computer.

PAJ: What were the highpoints of your tenure as Editor of North Carolina Libraries? Were their issues of the journal that you felt were especially noteworthy and timely in their coverage of topics of interest to the library community at large?

FBB: I have to confess that one of the greatest experiences was redesigning the journal back in the early 1990s. We went from a small journal to a full-sized magazine with a photographed cover. These were HUGE steps for the journal. Pat Weathersbee and I did this at her house after work several Fridays over the course of those few months. Gary would cook dinner and Pat and I would pour over her latest layout design. It was the most heady experience imaginable, almost like birthing a baby!

As for individual issues, I have always loved the local history issues - they really were the essence in great how-to-do-this-well manuals. And the issue in which we interviewed our older library leaders. They have so much to teach us. I hope you will continue those interviews on an occasional basis. We did an "extra" issue back in 1992 "Crisis in Librarianship." Howard McGinn was guest editor, and I think it clinched the second H.W. Wilson Award for us. (Yes, there were actually three H.W. Wilson Awards. The first was awarded in 1981, when Jonathan Lindsey was editor.) And, of course, I can't forget the 50th anniversary issue. My research for the history of the journal led to my entire future personal life — John Welch!

PAJ: Realizing that every endeavor has its disappointments as well as its elations, what were some of the problems you encountered as Editor? Were there situations you would have handled differently, if you were given the opportunity to address them afresh?

FBB: I guess my greatest disappointments came with some regularity. Having to reject an article has always been hard for me. People have so much of themselves invested when they write an article and send it off for publication - I know that from first-hand experience! Telling them that it needed work or was just not acceptable was horrible, and frankly, I often procrastinated. Another huge disappointment for me was when the school librarians decided to leave NCLA. I will always believe that we are more effective as one rather than separate organizations, but I just couldn't fight the overwhelming sentiment on that.

What would I handle differently? I don't spend a whole lot of time asking myself that question, but I guess I would have spent more time doing the job - I never felt I gave it enough time, especially the last couple of years. There was always something that could have been done better if I could have devoted more time to it.

PA): What have been the most difficult problems facing the North Carolina Library Association throughout the years of your tenure as Editor of North Carolina Libraries? How was the publication of the journal affected by those problems?

FBB: Money, and NCL was at the heart of issue. North Carolina Libraries has always been the major Association expense, and constantly justifying its existence was stressful and oh, so frustrating. We really were a very inexpensive publication when you looked at the cost of printing newsletters and bulletins, BUT we were a 
huge expense regardless of the rationale. It was the most inexpensive professional development anyone ever invested in, but it still was tough to finance. And basically the journal stopped growing because of it. We all know that nothing stays stagnate; it either goes forward or backward. I believe that inertia was hard for all of us to be a part of. For years we tried to make it appear that it was growing by changing features, etc., but I'm not sure we fooled anyone. Definitely not me!

PA): How do you view the transition from the print to the electronic publication of North Carolina Libraries? Are there special pitfalls that I as the new Editor and the new Editorial Board should avoid?

FBB: It was inevitable and it is certainly more financially viable. In truth, I worry about the wonderful professional growth and social experi-

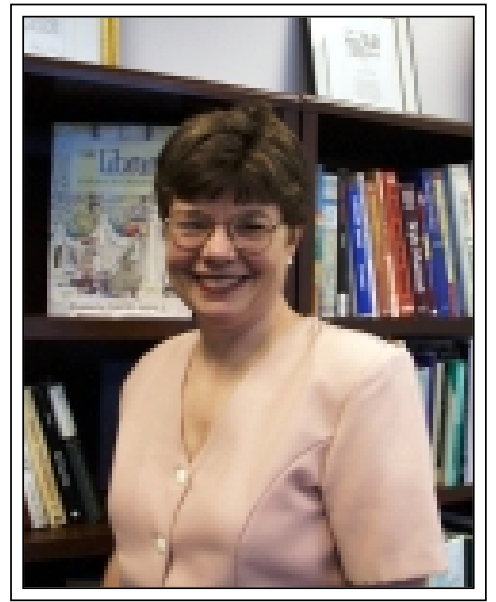
ences that will be lost without the editorial board meetings. I know I would have had a hard time building up a sense of community and loyalty without the regular face-to-face contact that our meetings and the yearly retreat fostered. I also confess to wondering who really reads online journals. I use them for research, but I don't just browse them at the doctor's office, during lunch - you know what I'm saying. I'm delighted that you plan to do at least one print issue - of the entire year's articles. I think that's a great compromise, and I'll look forward to getting my first issue!

PAJ: Where are you now in terms of your professional career and what do you think will be filling your time now that you have decided to step down as Editor of North Carolina Libraries? What are the special challenges and exciting opportunities ahead for you?

FBB: Let's not even go there! I'm writing this after having riffed 3 people in my division during this horrible state budget crisis and as we are waiting to find out the fate of our programs for the coming year. My greatest challenge is trying to keep school library media and instructional technology programs funded - and people in those positions - during this devastating time in our state's history. That's only considered exciting if you have a perverse sense of adventure!

PAJ: What special advice do you have for me as the new Editor and for the new Editorial Board of the electronic North Carolina Libraries?

FBB: Have fun and learn everything you can. I have said many times that working on the North Carolina Libraries Editorial Board was the very best professional development experience anyone can have. You are exposed to so many ideas as well as all the different areas of librarianship, and you are challenged to make our profession understandable and important to others. It's a wonderful opportunity — celebrate it!

PAJ: Thank you for sharing your reminiscences from your special vantage point as North Carolina Libraries Editor Emerita. I know that the members of the Editorial Board and I will be calling on you frequently for advice based on your seventeen years of experience at the helm of the best state library journal in the nation. Enjoy life to the fullest, Frances, and remember that your opinions matter now more than ever! 